Access to Justice in Eastern Europe,

Issue 4 (8) 2020

ISSN 2663-0575 (Print)

ISSN 2663-0583 (Online)

http://ajee-journal.com

10.33327/AJEE-18-3.4

$P$ Voitovych, $R$ Ennan, V Voloshyna

'Criminal Liability for the Infringement of IP Rights: Ukraine and the European Court of Human Rights Case Law'

(2020) 4(8) Access

to Justice in Eastern Europe 291-297

10.33327/AJEE-18-3.4-n000041

\title{
CRIMINAL LIABILITY FOR THE INFRINGEMENT OF IP RIGHTS: UKRAINE AND THE EUROPEAN COURT OF HUMAN RIGHTS CASE LAW
}

\author{
Voitovych Pavlo \\ PhD, Assoc. Prof. of the Department of International \\ and European Law, \\ National University ‘Odesa Law Academy’, Ukraine,
}

\section{Ennan Ruslan}

PhD, Assoc. Prof. of Department of Intellectual

Property Law and Corporate Law,

National University ‘Odesa Law Academy’, Ukraine

\section{Voloshyna Vladlena}

PhD, Assoc. Prof. of Department of Criminal Procedure, National University ‘Odesa Law Academy', Ukraine

Summary: 1. Introduction. - 2. Legal Regulation and Its Gaps. - 3. ECtHR Case Law and Its Impact on the Ukrainian Practice. - 4. Concluding Remarks. 
Ukraine's national legislation and the European Court of Human Rights's case-law outline Copyright protection. Many cases exist where the public significance and damage from copyright infringement entails holding the guilty person criminally responsible for the transgression. Given copyright infringement cases do not reflect a predominant concern over other crimes, a structured criminal prosecution mechanism does not exist. Thus, the European Court of Human Rights' legal positions and instructions intend to eliminate gaps legally regulating criminal liability for copyright infringement. Hence, the legal regulation, its gaps and ECHR case law impacts on Ukrainian practice were analysed. This structure enabled proposing steps for improving legally regulating criminal liability for copyright infringement in Ukraine.

Keywords: author's rights protection, criminal proceedings, ECtHR case law.

\section{INTRODUCTION: UKRAINIAN LEGAL REGULATION AND GAPS}

The World Wide Web has given rise to unprecedented copyright infringement cases, requiring a timely state response, especially criminal prosecution. Thus, Art. 176 of the Criminal Code of Ukraine (CC) provides for punishment for illegal reproduction, distribution of works of science, literature, art, computer programs, and databases, and illegal reproduction, distribution of performances, phonograms, videograms, and broadcasting programs, their illegal reproduction, and distribution on audio and videotapes, diskettes, other media, camcording, card sharing or other intentional infringement of copyright and related rights, and the financing of such actions if causing material damage. ${ }^{1}$ This CC article provides punishments, including fines, correctional labour, arrest, liberty restraint, and imprisonment.

Criminal liability regulation for copyright infringement related rights has proven challenging to consider, as it raises many questions that need to be answered. Thus, the calculation and material damage proof (compensation and determination of non-pecuniary damage and violation intent degree) have caused significant misunderstandings. The latter is still debated in legal theory. Therefore, according to some experts, intentional guilt characterizes copyright infringement, as any error in using the copyright object does not constitute a crime. Some scholars have suggested appropriately excluding from the disposition of CC Part 1 of Art. 176, the words 'intentional' to criminalize deliberate and negligent. ${ }^{2}$

Criminal liability does not comprise the only legal liability for copyright infringement. Its strictest application, criminal liability, should consider the social danger of action and consequences and the internal personal attitude to intend. Practically, a negligent copyright protection crime is difficult to imagine, for it must lead to material damage to the copyright subject increased danger to societal

\footnotetext{
1 The Criminal Code of Ukraine (Verkhovna Rada of Ukraine, 5 April 2001) <https://zakon.rada.gov.ua/ laws/show/2341-14/stru\#Stru> accessed 20 October 2020.

2 OO Posykalyuk, 'Balance between the right to information and the right of intellectual property in the practice of the European Court of Human Rights' [2017] International Congress of European Law (Phoenix, Odesa) 328-332.
} 
interests. Another disadvantage of regulating criminal liability for copyright infringement involves the non-exhaustive list of objects, objects of copyright, falling under CC Art. 176. Expressly, liability under this article arises for intentional copyright infringement, broadly interpreting objective sides and copyright the object of a crime.

According to paragraph 17 of Part 1 of Art. 8 of the Law of Ukraine On Copyright and Related Rights, copyright objects include 'other works.' 3 The openness of the list (although detrimental to object encroachment certainty within criminal liability) remains progressive, as it leaves space for new human creativity incarnations. The modern information society has encouraged innovative genres, as many copyright objects are currently created based on information technologies. For example, the legality and affiliation of a particular website or account category have remained uncertain. The website should enjoy copyright regulation because of internal content, functionality, design, and purpose. The website can claim a creator created individuality. However, one copyright object can infringe on another object's rights. Thus, websites incorporate copyrighted material, like film, music, and literature. When prosecuting acts committed through websites using CC Art. 176 , it should be remembered the website also claims copyrights. When applying the penalty, one should consider the line between copyright infringement and website copyright possibly violated by web blocking. Ukrainian legislation does not provide for copyright crime blocking as a sanction. However, rapid information technology development in modern life has not excluded the possibility of further use of web-blocking as an injunction, including the obligation to refrain from specific actions. When prescribing this measure, it should be borne in mind, copyright is infringed not by the web page's existence, but its content, for example, digitally placing a separate work on the Internet. Other copyrights may be lawfully incorporated in the website, so blocking access to them may violate others' legal rights and interests.

\section{ECTHR CASE LAW AND ITS IMPACT ON THE UKRAINIAN PRACTICE}

The ECtHR's case-law aims to maintain the general spirit of law and justice, set guidelines for national courts in resolving criminal proceedings concerning copyright infringement, and restore the violated rights. The primary paradigm of intellectual property law, in particular copyright, expressed in the precedents of the ECtHR, combines three components: 1) protection against public authority arbitrary interference; 2) positive state obligation to introduce a mechanism for ensuring intellectual property rights; 3 ) ensuring minimum and maximum protection intellectual property rights standards. It should be considered a copyright intellectual property feature, including copyright objects, in the sense of the ECtHR falls under the category of property, protected by Art. 1 of the First Protocol to the Convention

3 The Law of Ukraine 'On copyright and related rights' [1994] Vidomosti of the Verkhovna Rada 13/64 (with amendments of 16 June 2020) <https://zakon.rada.gov.ua/laws/show/3792-12\#Text> accessed 19 October 2020. 
for the Protection of Human Rights and Fundamental Freedoms (Protocol). ${ }^{4}$ Melnychuk v. Ukraine, ${ }^{5}$ Anheuser-Bush Inc. v. Portugal exemplified these decisions. ${ }^{6}$ This Protocol also applies to the right to publish a translation (SC Editura Orizonturi SRL v. Romania), ${ }^{7}$ musical works, and economic license agreement interests (SIA AKKA / LAA v. Latvia).

An unusual interpretation of the object of intellectual property rights as property can be justified in terms of the traditional perception and the relationship identification of property damage the crime caused by the object of encroachment. Inclusion property of not only traditional items but also other objects, such as intellectual property, given the binding legal European Court opinions on the interpretation and application of the Convention for the Protection of Human Rights and Fundamental Freedoms (Convention), extends the protection mechanism laid down in Article 1 of the First Protocol to legal phenomena beyond the traditional for the Romano-Germanic legal property as a corporeal material world object (things). ${ }^{9}$

The Convention does not directly reference the human right to intellectual property, so the inclusion of this right in this legal category expands the protection of the infringed right through a supranational judicial institution, the ECtHR. After analyzing the ECtHR practice, it can be concluded the cases related to copyright remain significantly inferior in quantitative criteria to other cases, such as cases concerning the property in its typical form.

However, ECtHR case law has indispensably bridged the gap between national law and legal awareness. A striking example, especially within the legal consciousness, entails repeatedly emphasising the ECtHR's decisions on the relationship of copyright with freedom of expression, protected by Art. 10 of the Convention. Thus, according to the plot of Nage and Sunde Colmisoppi v. Sweden's case,$^{10}$ the applicants created and promoted a website exchanging files containing various copyrighted objects (cinematographic works, musical works, computer games) between users. A copyright offence was committed because they facilitated the transfer of these files without the copyright holder's proper permission. In its ruling, in this case, the ECtHR expressed states should balance the two competing interests. However, copyright can prevail over the right and freedom of expression and is therefore recognized as a legitimate restriction.

4 Council of Europe, Protocol to the Convention for the Protection of Human Rights and Fundamental Freedoms [1952] ETS 009 <https://www.coe.int/en/web/conventions/full-list/-/conventions/ treaty/009> accessed 19 October 2020.

5 Melnychuk $v$ Ukraine (App no 28743/03) Reports of Judgments and Decisions 2005-IX <http://hudoc. echr.coe.int/eng? $\mathrm{i}=001-70089>$ accessed 19 October 2020.

6 Anheuser-Bush Inc $v$ Portugal (App no 73049/01) ECHR 11 January 2007 <https://hudoc.echr.coe.int/ eng\#\{\%22itemid\%22:[\%22001-78981\%22]\}> accessed 19 October 2020.

7 SC Editura Orizonturi SRL v Romania (App no 15872/03) ECHR 13 April $2008<$ http://hudoc.echr.coe. int/eng?i=001-122507/> accessed 19 October 2020 .

8 SIA AKKA/LAA v. Latvia (App no 562/05) ECHR 10 October 2016 <http://hudoc.echr.coe.int/ eng?i=001-164659> accessed 19 October 2020.

9 NE Blazhivska, 'Interpretation of the concept of property in the practice of the European Court of Human Rights' (2018) 10 Entrepreneurship, economy and law 219-223.

10 Fredrik NEIJ and Peter SUNDE KOLMISOPPI $v$ Sweden (App no 40397/12) ECHR 19 February 2013 $<$ http://hudoc.echr.coe.int/eng?i=001-117513/> accessed 19 October 2020. 
The ECtHR expressed the same position in the judgment in Ashby Donald and Others $v$. France, ${ }^{11}$ concerning the prosecution of photographers posting photos from a fashion show on the Internet without the fashion designers' permission. The clothes were shown at the show and displayed in the relevant photos. In this case, the ECtHR also recognized the priority of designers' copyright over photographers' freedom of expression. However, this position cannot be accepted unconditionally because, in this case, the copyright to various objects: fashion designers (clothes depicted in photographs), and photographers (photograph as a separate art form) possess copyright. Along with its judgment in Akdeniz v. Turkey, ${ }^{12}$ the ECtHR ruled 'when it comes to striking a balance between potentially conflicting interests, such as the right to freedom of information and the protection of copyright - Public authorities have a particularly wide margin of discretion.' In Ahmet Yildirim v. Turkey, ${ }^{13}$ the ECtHR found a violation of Art. 10 of the Convention and applied a measure of completely blocking the applicant's access as owner and user of Google Sites services to these services (including access to his account). However, the crime (violation of Ataturk's memory) was committed only on one of these service pages. This illustrates the punishment should be commensurate with the crime committed and ensure the established balance between the parties' interests in the dispute.

Liability for copyright infringement is often accompanied by illegal property rights infringement in standard interpretation. Thus, at the beginning of the year, the ECtHR in Pendov v. Bulgaria ${ }^{14}$ considered the lawfulness of the law enforcement agencies' detention of a server under Art. 8, 10 of the Convention, ${ }^{15}$ and Art. 1 of the Protocol. ${ }^{16}$ Thus, during the criminal proceedings, the criminal justice authorities confiscated from the applicant a server on which a website had been partially placed, utilizing a book with copyright infringement had allegedly been uploaded to the Internet. These authorities did not consider another website owned by the infringer was also hosted on the removed server. Presently, the website represents a specific material value because, in particular, it embodies the conventional expectations within the limits of Art. 1 of the Protocol are recognized by the ECtHR as property. The ECtHR found the server's retention was disproportionate since the information required for the criminal proceedings and copyright infringement could be copied and deleted without removing the server, as it contained the information necessary to the applicant's professional activities. By this decision, the ECtHR recognized Bulgaria's

11 Ashby Donald and Others $v$ France (App no 36769/08) ECHR 10 January 2013 <http://hudoc.echr.coe. int/eng?i=001-115845 > accessed 19 October 2020.

12 AKDENIZ v TURKEY (App no 25165/94) ECHR 31 May 2005 <http://hudoc.echr.coe.int/ eng? $\mathrm{i}=001-69196>$ accessed 19 October 2020.

13 AHMET YILDIRIM v TURKEY (App no 3111/10) ECHR 18 December 2012 <http://hudoc.echr.coe. int/eng?i=001-115705 $>$ accessed 19 October 2020.

14 PENDOV $v$ BULGARIA (App no 44229/11) ECHR 26 March $2020<$ http://hudoc.echr.coe.int/ eng? $\mathrm{i}=001-201890>$ accessed 19 October 2020.

15 Council of Europe, Convention for the Protection of Human Rights and Fundamental Freedoms [1950] ETS $5<$ https://www.echr.coe.int/documents/convention_eng.pdf> accessed 19 October 2020.

16 Council of Europe, Protocol to the Convention for the Protection of Human Rights and Fundamental Freedoms [1954] ETS 9 <https://www.coe.int/en/web/conventions/full-list/-/conventions/treaty/009> accessed 19 October 2020. 
violation of Art. 1 of the Protocol (property rights) ${ }^{17}$ and Art. 10 of the Convention (right to freedom of expression). ${ }^{18}$

The ECtHR decision in Pendov v. Bulgaria also reflects the case law of Ukraine, as the Verkhovna Rada of Ukraine has a Draft Law on Amendments to the CPC and the CC of 15 January 2020, establishing within the procedural measures for temporary access to things and documents, access will be provided only for the information extraction contained on servers or information technology material objects. ${ }^{19}$ Hence, hardware seizure will be allowed only if an information destruction risk without a seizure is proven.

The Law of Ukraine On Copyright and Related Rights classifies as copyright infringement any actions for deliberate circumvention of technical means of protecting copyright and related rights. However, Ukraine's criminal legislation does not provide criminal liability for these actions' commission, unveiling an omission to which the Ukrainian legislator should pay attention. The Law of Ukraine On Copyright and Related Rights defines technical means of protection as technical devices or technological developments designed to create a technological barrier to copyright infringement or related rights in the perception or copying of protected (encrypted) records in phonograms (videograms) and broadcasts of broadcasting organizations or to control access to the use of copyright and related rights. In practice, technical means of protection encompass hardware (technical devices) and software products (technological schemes and solutions). ${ }^{20}$

A situation technically circumventing protection, the actual commission of copyright infringement could be performed with computer development or a program to which the copyright regime also applies. In this case, deciding in favour of the first author would infringe on another's copyright, even though the relevant copyright object was created to achieve an illegal purpose.

Having analyzed the ECtHR's case-law, the authors have not found a specific solution to the question comparing competing copyrights. This issue should spark further copyright infringement research.

\section{CONCLUDING REMARKS}

Legally regulating criminal liability for copyright infringement in Ukraine should be considered insufficient due to many reasons, including:

1. insufficient state attention paid to copyright infringement;

17 Protocol (n 18).

18 Convention (n 17).

19 Draft Law 'On Amendments to the Criminal Procedure Code of Ukraine and the Criminal Code of Ukraine' <http://w1.c1.rada.gov.ua/pls/zweb2/webproc4_1?pf3511=67872> accessed 19 October 2020.

20 O Rassomakhina, 'Technical means of protection of copyright and related rights on the Internet: issues of legal regulation' (2012) 11 Yurydychna Ukraina 70-71 <http://nbuv.gov.ua/UJRN/urykr_2012_11_13> accessed 19 October 2020. 
2. relatively fledgling and not fully formed institution of copyright protection within substantive and procedural legislation (civil, administrative, and criminal jurisdictions);

3. delayed state response to new modern challenges, particularly digitalization;

4. legal nihilism and negative legal awareness.

After analyzing the ECtHR copyright protection, the central positions related to private law regulation emerged. Criminal law copyright protection in Ukraine remains, in most cases, declarative and does not properly fulfill its functional purpose. Thus, ECtHR's case-law determines the vector of development and improvement of the national legal system within the provision, protection, and defense of intellectual property and the courts' practical activities and other criminal justice authorities in Ukraine's criminal proceedings. 